\title{
Construction and Implementation of Standard System for Rural Household Toilets in China
}

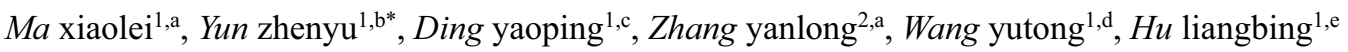 \\ ${ }^{1}$ China National Institute of Standardization, Haidian District, Beijing, China \\ ${ }^{2}$ Rural Development Institute Chinese Academy of Social Sciences, Dongcheng District, Beijing, China
}

\begin{abstract}
Promoting the "toilet revolution" in rural areas is an important measure to improve the rural living environment and realize rural revitalization. Standardizing the construction and management of rural household toilets by means of standardization is of great significance for the high-quality completion of the "toilet revolution". Based on the policy and current situation of the transformation of rural household toilets in China, this paper studies and analyzes the current situation of standardization of rural household toilets, expounds the construction principles of standard system for rural household toilets, constructs the standard system framework including comprehensive general use, facilities and equipment, construction acceptance, management and protection, and finally puts forward some countermeasures and suggestions to promote the implementation of the standard system.
\end{abstract}

\section{Preface}

Small toilet, big people's livelihood. As an essential basic sanitary facility in people's daily life, toilet is an important indicator to reflect the level of social civilization. For a long time, dry latrine is a traditional type of toilet widely used in rural areas. However, dry latrine is lack of facilities for collection and treatment of feces and urine, which easily leads to the spread of a large number of worm eggs, bacteria and pollutants, polluting the living environment and seriously threatening human health. In order to speed up the improvement of village environment and promote the construction of beautiful and livable villages, the State Council issued the Guidance on Improving the Rural Living Environment in 2014, proposing to promote the transformation of rural household toilets. Over the years, remarkable results have been achieved in the reform of rural household toilets in China through the joint efforts of all sectors of society. It can be seen from China Health Statistics Yearbook that the popularization rate of sanitary toilets in China increased from $20.9 \%$ in 1996 to $81.80 \%$ in 2017.a However, there are still some problems in the actual toilet transformation work, such as unbalanced regional development ${ }^{[1]}$, unscientific design, emphasis on speed over quality [2], emphasis on construction over management ${ }^{[3]}$, which restrict the process of "toilet revolution" and the effect of toilet transformation.

As a recognized measurement and norm, standardization is an important means to ensure the construction quality of household toilets, improve the transformation effect and improve the management and maintenance mechanism. Therefore, how to promote the "toilet revolution" by means of standardization, how to build the standard system for rural household toilets at the macro level, and how to make overall management of various types of standardization achievements are the important tasks that need to be improved in the current standardization work in the process of transformation of rural household toilets in China. For this purpose, based on the policy and current situation of transformation of rural household toilets, this paper puts forward the construction principles and elements of the standard framework through study and analysis of the current situation of standardization of rural household toilets, explores the construction of standard system for rural household toilets in China, and makes proposals on policy to promote the implementation of the standard system on this basis.

\section{Policy guidance for transformation of rural household toilets in China}

\subsection{Sorting-out of national policies}

The 18th CPC National Congress put forward the construction concept of "Beautiful China" in 2012. Taking this as an opportunity, the renovation of rural living environment was written into the "No. 1 Document" of the central government for the first time in January 2014. In 2017, the 19th CPC National Congress put forward the strategy of rural revitalization, in which "ecological livable" is recognized as one of the general requirements,

$\overline{{ }^{*} \text { Corresponding author: yunzy@cnis.ac.cn }}$ 
putting forward higher requirements for the renovation of rural living environment and the transformation of household toilets. In February 2018, the General Office of the CPC Central Committee and the General Office of the State Council issued the Three-Year Action Plan for the Renovation of Rural Living Environment. Since then, the Ministry of Agriculture and Rural Affairs, the Ministry of
Finance, the National Health Commission and other departments have issued a series of policy documents on the issues of "toilet revolution" model establishment, financial rewards and subsidies, toilet transformation standards and quality, etc., and the central level policy framework system has been gradually improved (Table 1).

Table 1. Some policy documents of the central government on transformation of rural household toilets since 2013

\begin{tabular}{|c|c|c|}
\hline Year & Policy document & Issuance unit \\
\hline 2014 & Guidance on Improving the Rural Living Environment & General Office of the State Council \\
\hline 2014 & $\begin{array}{l}\text { Notice on Further Promoting the Transformation Work of Toilets in } \\
\text { Rural Areas }\end{array}$ & National Patriotic Health Campaign Committee \\
\hline 2018 & $\begin{array}{c}\text { Notice of the General Office of the CPC Central Committee and the } \\
\text { General Office of the State Council on Issuing the Three-Year } \\
\text { Action Plan for the Renovation of Rural Living Environment }\end{array}$ & $\begin{array}{l}\text { General Office of the CPC Central Committee } \\
\text { and General Office of the State Council }\end{array}$ \\
\hline 2018 & $\begin{array}{l}\text { Notice on Action for Steady Promotion of Renovation of Rural } \\
\text { Living Environment }\end{array}$ & National Development and Reform Commission \\
\hline 2018 & $\begin{array}{c}\text { Notice on Further Promoting the Construction of Rural Household } \\
\text { Toilets }\end{array}$ & National Patriotic Health Campaign Committee \\
\hline 2018 & $\begin{array}{l}\text { Guidance on the Special Action for Promotion of "Toilet } \\
\text { Revolution" in Rural Areas }\end{array}$ & $\begin{array}{l}\text { Central Rural Work Leading Group, the Ministry } \\
\text { of Agriculture and Rural Affairs, the Ministry of } \\
\text { Housing and Urban Rural Development, the } \\
\text { Ministry of Culture and Tourism, National } \\
\text { Development and Reform Commission, Ministry } \\
\text { of Finance, Ministry of Ecology and Environment } \\
\text { and National Health Commission }\end{array}$ \\
\hline 2019 & $\begin{array}{c}\text { Notice on Carrying out "Toilet Revolution" in Rural Areas and } \\
\text { Promoting Financial Reward and Subsidy Work in the Whole } \\
\text { Village }\end{array}$ & $\begin{array}{c}\text { Ministry of Finance, Ministry of Agriculture and } \\
\text { Rural Affairs }\end{array}$ \\
\hline 2019 & $\begin{array}{c}\text { Notice on the Selection and Promotion of Typical Models of Rural } \\
\text { Toilet Waste Treatment and Resource Utilization }\end{array}$ & $\begin{array}{l}\text { Ministry of Agriculture and Rural Affairs, } \\
\text { National Health Commission, Ministry of } \\
\text { Ecological Environment }\end{array}$ \\
\hline 2020 & $\begin{array}{c}\text { Notice on Issuance of Technical Requirements for Construction of } \\
\text { Rural Household Toilets (Trial) }\end{array}$ & $\begin{array}{l}\text { General Office of the Ministry of Agriculture and } \\
\text { Rural Affairs and National Health Commission }\end{array}$ \\
\hline
\end{tabular}

Data source: Based on publicly available materials.

\subsection{Analysis of provincial policy guidance}

Under the guidance of the central policy documents, various regions at the provincial level have issued a large number of policy documents on the renovation of rural living environment and the transformation of household toilets according to local conditions. From the analysis of local policy guidance and the popularization of sanitary toilets, there are mainly three stages of the transformation of rural household toilets in the provinces of China, namely, the acceleration period, the critical period, and the high-level promotion period, as shown in Figure 1.

The popularization rate of rural sanitary toilets in the provinces is relatively low in the accelerating stage, and the policy for transformation of rural household toilets focuses on improving the popularization level of sanitary toilets. In terms of toilet transformation strategy, the way of "decision-making by superior government, top-down promotion and implementation by grass-roots government" is mainly adopted; In terms of fund-raising, as the development of village level collective economy generally lags behind, more emphasis is put on the combination of government financial subsidies and residents' fund and labor investment; The establishment of long-term mechanism is still in its infancy, and the operation and management institutionalization level of all kinds of toilets is accelerating.

The popularization rate of rural sanitary toilets in the provinces in the critical period is at the middle level. These provinces usually introduce special action plans for the "toilet revolution" in rural areas, and also introduce supporting measures from the aspects of organization and leadership, fund raising and use, etc. In terms of toilet transformation strategy, it not only emphasizes the overall planning of the superior government, but also gives full play to the initiative of the grass-roots government; In the way of fund-raising, the local government takes the toilet transformation project as the starting point, strengthens the policy support, and widely uses the way of reward instead of subsidy; In terms of management mode, the household toilet archives management mode should be 
established to ensure the quality of household toilet renovation and subsequent management level.

The popularization rate of rural sanitary toilets in the provinces at the stage of high-level promotion is relatively high. These provinces are in a high level of economic development, and have strong financial strength of the government. The transformation of household toilets started early. The government's policies for renovation of rural household toilets mostly focus on transformation upgrading and high-level promotion, as well as the toilet transformation quality, systematicness and planning; In terms of toilet transformation strategy, with significant characteristics of participation in it as a leader, the grass- roots government plays a leading role in formulating the planning for renovation of urban and rural residential environment, and integrates the rural household toilet transformation into the construction of ecological livable countryside through planning guidance and system improvement; In terms of fund raising methods, based on the rural collective economy, it has significant characteristics of the combination of public finance, land value-added income and rural collective economic income as well as diversified financing methods; It is accelerating to form a long-term management and protection mechanism with "available system, standard, team, fund and supervision".

\begin{tabular}{|c|c|c|c|}
\hline & $\begin{array}{l}\text { Acceleration } \\
\text { period }\end{array}$ & Critical period & $\begin{array}{l}\text { Consolidation } \\
\text { and promotion } \\
\text { period }\end{array}$ \\
\hline Focus point & $\begin{array}{l}\text { The popularization level of } \\
\text { sanitary toilets has been } \\
\text { improved, and large-scale } \\
\text { construction of toilets has been } \\
\text { carried out }\end{array}$ & $\begin{array}{l}\text { The popularization level of } \\
\text { sanitary toilets has been } \\
\text { improved with the fecal } \\
\text { management, and the } \\
\text { collection and disposal of } \\
\text { sewage }\end{array}$ & $\begin{array}{l}\text { Transformation and upgrading of rural } \\
\text { household toilets, unified treatment of } \\
\text { urban and rural domestic sewage, } \\
\text { construction of rural living } \\
\text { environment construction and } \\
\text { management system }\end{array}$ \\
\hline $\begin{array}{c}\text { Toilet } \\
\text { transformation } \\
\text { strategy }\end{array}$ & $\begin{array}{l}\text { Standardized policy implementation } \\
\text { mode, decision-making by the } \\
\text { superior government, top-down } \\
\text { promotion, implementation by } \\
\text { inferior government }\end{array}$ & $\begin{array}{l}\text { Adjust measures to local } \\
\text { conditions, make one policy } \\
\text { for each village, concentrate } \\
\text { on the contiguous area and } \\
\text { promote in the whole village }\end{array}$ & $\begin{array}{c}\text { Grass-roots government's } \\
\text { participation as a leader, } \\
\text { planning guidance and system } \\
\text { improvement }\end{array}$ \\
\hline
\end{tabular}

\begin{tabular}{|c|c|c|c|}
\hline Fund raising & $\begin{array}{l}\text { The combination of } \\
\text { government financial } \\
\text { subsidies and residents' } \\
\text { fund and labor } \\
\text { investment }\end{array}$ & $\begin{array}{l}\text { Completion acceptance, } \\
\text { reward instead of subsidy }\end{array}$ & $\begin{array}{l}\text { Public finance, land value- } \\
\text { added income, financial } \\
\text { support, rural collective } \\
\text { economic income }\end{array}$ \\
\hline
\end{tabular}

\begin{tabular}{|c|c|c|c|}
\hline $\begin{array}{l}\text { Long-term } \\
\text { operation }\end{array}$ & $\begin{array}{l}\text { Territorial management, } \\
\text { hierarchical responsibility, low } \\
\text { level of institutionalization }\end{array}$ & $\begin{array}{l}\text { For the transformation of } \\
\text { newly-built toilets, } \\
\text { household toilets should be } \\
\text { filed and kept for future } \\
\text { reference }\end{array}$ & $\begin{array}{c}\text { "Available system, } \\
\text { standard, team, fund and } \\
\text { supervision" }\end{array}$ \\
\hline
\end{tabular}

Fig. 1. Main policy characteristics of transformation of rural household toilets in China

\section{Current situation and problems of transformation of rural household toilets in China}

\subsection{Analysis on current situation of transformation of rural household toilets in China}

It can be seen from China Health Statistics Yearbook that types of sanitary toilets in China include three-chamber septic tank type, double-urn funnel type, triple biogas tank type, manure and urine diversity type, complete sewer flushing type, double-pit alternate type and other types currently.

In 2017, the popularization rate of rural sanitary toilets in China increased steadily, reaching $81.8 \%$, of which the three-chamber septic tank type is the mainstream of sanitary toilets, accounting for $37.59 \%$. From the regional level, it can be seen through analysis that the popularization rate of rural sanitary toilets in the eastern, central and western regions decreases in turn. The eastern region is dominated by three-chamber septic tank type; the central region is dominated by complete sewer flushing type and three-chamber septic tank type, and the western region is dominated by complete sewer flushing type. From the provincial levelb, the popularization rate of rural sanitary toilets in half of provinces is above the national average level, among which, the highest popularization rate is $99.2 \%$ in Shanghai, and the lowest popularization rate is $47.2 \%$ in Shaanxi.

\footnotetext{
${ }^{2}$ There is a lack of Tibet data in the statistics yearbook.
} 


\subsection{Analysis on the problems in transformation of rural household toilets in China}

(1) Unscientific planning and design, low product quality .In some areas, when designing the transformation scheme, it is not combined with the local reality, which affects the construction, use and maintenance of toilets. For example, if outdoor flushing type toilets are constructed in the cold and dry Gansu and other places, on the one hand, it will not be matched with the local water resources conditions, and on the other hand, the toilet will be very easy to freeze for lack of appropriate heat preservation measures, affecting the use effect. In addition, through investigation and study, relevant scholars found that ${ }^{[4]}$ many villages use low-quality equipment products for saving costs in the process of toilet transformation in reality.

(2) The pressure of fund investment is high, and the willingness of rural households to participate is low. At present, government subsidies and rural households' input are often used in the transformation of rural toilets, but even so, for poor rural households, the cost of toilet transformation is still a large expenditure. Moreover, the later maintenance costs are high, such as water and electricity, sewage treatment and other operation and management costs of flushing type sanitary toilets, which greatly increases the living costs of rural households and reduces their willingness to participate in toilet transformation.

(3) The management and maintenance mechanism needs to be improved, and the resource utilization rate of feces is low. Although there are remarkable achievements in the popularization rate of sanitary toilets, there is a common problem of "emphasis on construction over management". There is no tracking management and feedback on the use of rural household toilets, and there is a lack of long-term and sustainable management mechanism. In the aspect of fecal treatment, it mainly relies on the mode of mutual assistance of village collective rural households, lacks centralized treatment equipment and operation and maintenance measures, and professional fecal treatment companies and institutions have not joined the maintenance team of rural household toilets.

\section{Current situation of standardization of rural household toilets in China}

In recent years, in order to further improve the rural living environment and accelerate the "toilet revolution" in rural areas, China has formulated and implemented some standards in the sanitation, facilities and equipment and construction of rural toilets, which has played a certain role in promoting the transformation of rural toilets.

One of the main pionts of the "toilet revolution" lies in the sanitary effect. Focusing on the sanitary aspect of household toilets, China has issued two important standards, namely Hygienic Specification for Rural Household Latrine (GB/T 19379-2012) and Hygienic Requirements for Harmless Disposal of Night Soil (GB 7959-2012), specifying the sanitary requirements and evaluation methods for household toilets. These two national standards are mainly used in the renovation of household toilets in all regions, so there is no corresponding local standard.

Focusing on the equipment products involved in the transformation of rural household toilets, the national standards and industry standards mainly focus on flushing equipment, toilet stools and other ancillary facilities, such as Fixtures for Bathroom (GB/T 12956-2008), Sanitary Fixture for Water Saving (GB/T 31436-2015), Sanitary Ware - Smart Toilet (GB/T 34549-2017) and other national standards and Thermo Plastic Septic Tank (CJ/T 4892016), Armrest for Toilet (JC/T 2120-2012) and other industry standards. In addition, provinces are also actively exploring the issuance of local standards. For example, Shandong Province has issued Three-chamber Integrated Septic Tank (PE, PP, GFRP) (DB37/T 2792-2016).

In the construction acceptance of rural household toilets, the existing national standards involve limited types of toilets, which is difficult to meet the differentiated needs of different places. At present, the state has issued the Technical Specification for Construction of Rural Household Latrine with Three-Compartment Septic Tank (GB/T 38836-2020), Technical Specification for Construction of Rural Household Latrine Connected to A Sewer System (GB/T 38838-2020) and other national standards, but has not involved in the construction standard of non-flushing type sanitary toilets. As for the limited types and number of industry standards issued, there are only two industry standards at present, such as Code for Design of Night Soil Treatment Plant (CJJ 642009) and Technical Requirements for the Installation of Toilets (JC/T 2425-2017). In contrast, there are many standards for toilet construction and reconstruction issued in all regions, applicable to local conditions: Hubei Province has issued the Standard Guide for Construction of Rural Harmless Toilet (DB42/T 1495-2019); Shandong Province has issued the Biodegradable Water Free Toilets (DB37/T 1213-2009), and Shaanxi Province has issued the Rural Human Inhabitation Environment - Toilet Requirements (DB61/T 1272-2019).

In terms of toilet management and maintenance, the revision of national standards lags behind the actual needs of transformation of rural toilets, and the lack of management and maintenance standards is the main problem at present. At present, the state has issued Technical Requirements of Gas Monitoring for Sewer and Septic Tanks (GB/T 28888-2012), Specification for Operation and Maintenance of Rural Household Latrine with Three-Compartment Septic Tank (GB/T 38837-2020) and other relevant national standards in this regard. The standards involve relatively few types of toilets, and specific standards for evaluation of operation effect of rural household toilets are lack of. However, the industry standards only involve the operation and evaluation of fecal treatment plants, such as Technical Specification for Operation Maintenance and Safety of Night Soil Treatment Plant (CJJ 30-2009) and Standard for Assessment of Night Soil Treatment Plant (CJJ/T 2112014). Some developed provinces have changed from "emphasis on construction" to "emphasis on management", and issued relevant standards for the management and 
protection of rural household toilets. For example, Shandong Province has issued the Specification for Use and Maintenance of Rural Harmless Sanitary Toilet (DB37/T 2867-2016).

\section{Construction of standard system for rural household toilets in China}

\subsection{Principles of standard system construction}

(1) Overall coordination. The standard system of rural household toilets should be comprehensive. We should not only pay attention to the key links such as design, construction, acceptance, operation and maintenance of rural household toilets, but also formulate specifications from different dimensions such as technology, product and management, so as to play a comprehensive supporting role of standardization. Meanwhile, the standard system should be coordinated and stable as a whole. Horizontally, the subsystems are interrelated and complementary to each other; Vertically, national, industrial and local standards do not contradict, but are connected and coordinated with each other.

(2) Scientific and reasonable. The construction of standard system for rural household toilets should match with the policy documents such as Guidance on Improving the Rural Living Environment, Three-Year Action Plan for the Renovation of Rural Living Environment and Guidance on the Special Action for Promotion of "Toilet Revolution" in Rural Areas. Meanwhile, the theoretical and practical research results of rural household toilets in academic circles are absorbed to ensure the scientific and reasonable standard system.

(3) Adjust measures to local conditions. Considering the differences of factors such as geography, climate, customs, economic development stage, industrial development characteristics and actual needs of rural residents in different regions, we should establish a comprehensive and systematic standard system to meet the needs of toilet transformation in different regions, pay attention to the universality and practicability of the standard system construction, and encourage all regions to continuously enrich and improve the standard subsystem according to the actual situation of the region under the guidance of the existing standard system framework.

(4) Dynamic optimization. On the one hand, we should continue to absorb advanced technology in the construction of standard system for rural household toilets to make the standard system for rural household toilets more scientific and effective. On the other hand, according to the changes of the actual conditions, demands and environment of the transformation and construction of rural household toilets, we should dynamically adjust the content of the standard system, promote the construction of the standard system for rural household toilets in a planned, hierarchical and step-by-step way, and constantly enrich and improve the standardization system for rural household toilets.

\subsection{Standard system framework}

Based on the above construction principles, combined with the actual needs of transformation of rural household toilets in China, the basic framework of standard system for rural household toilets in China is constructed (Figure 2 ), including comprehensive general use standard subsystem, standard subsystem for facilities and equipment, standard subsystem for construction acceptance and standard subsystem for management and protection.

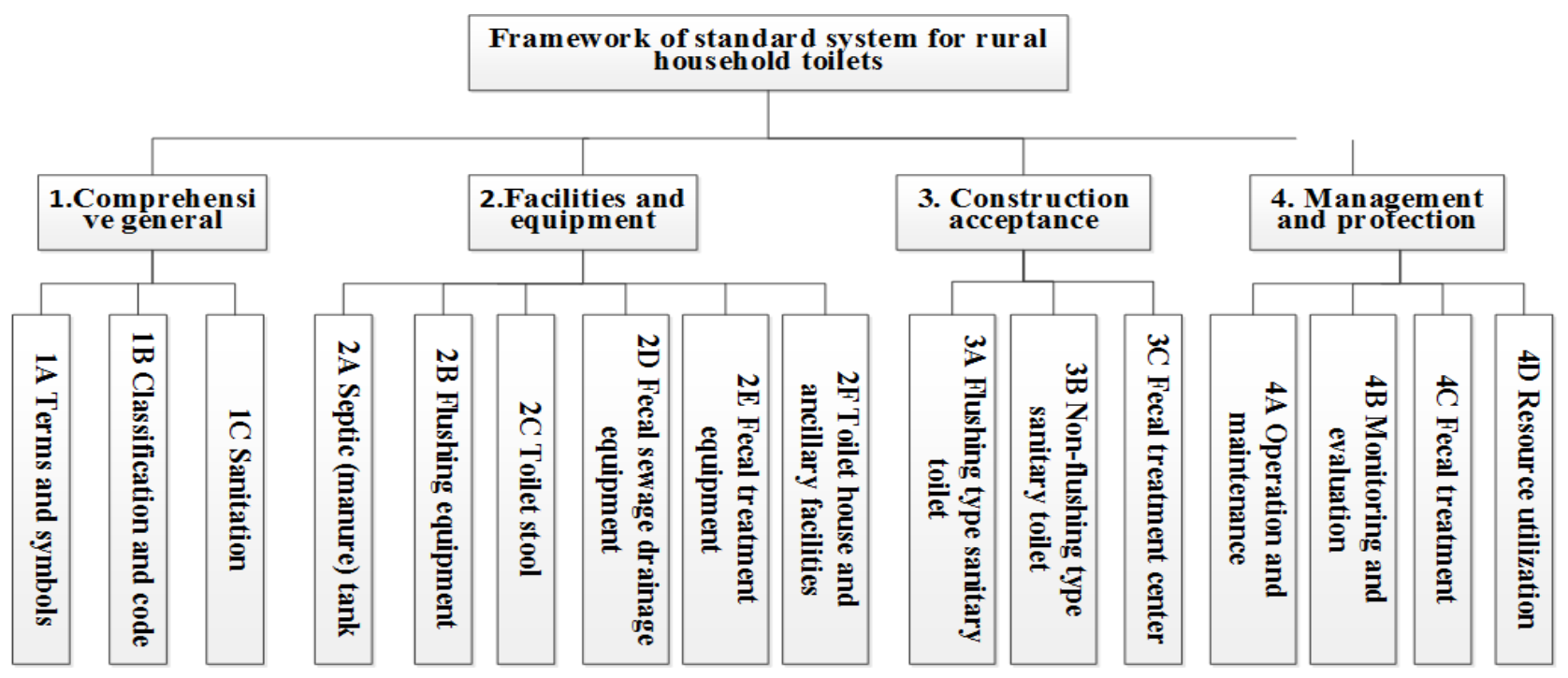

Fig. 2. Framework diagram of standard system for rural household toilets

(1) Comprehensive general use standard subsystem. It includes terms and symbols, classification and code, and sanitation.

(2) Standard subsystem for facilities and equipment. It includes six sub-categories: septic (manure) tank, flushing equipment, toilet stool, fecal sewage drainage equipment, fecal treatment equipment, toilet house and ancillary facilities. 
(3) Standard subsystem for construction acceptance. It includes three sub-categories: flushing type sanitary toilet, non-flushing type sanitary toilet and fecal treatment center.

(4) Standard subsystem for management and protection. It includes four sub-categories: operation and maintenance, monitoring and evaluation, fecal treatment and resource utilization.

\section{Conclusions and suggestions}

This paper further analyzes the current situation and demand of household toilet standardization through the study on the policy orientation of "toilet revolution" and the current situation of toilet transformation, and constructs the framework of standard system for rural household toilets suitable for China's development characteristics, and obtains the main study conclusion as follows:

First of all, based on the analysis of the local policy guidance and the popularization of sanitary toilets, it can be seen that the transformation of rural household toilets in China is mainly divided into three periods, namely, the acceleration period, the critical period, and the high-level promotion period. Secondly, although the popularization rate of rural sanitary toilets in China has been rising steadily, there are still some problems, such as unscientific planning and design, low product quality, high pressure of capital investment, low willingness of farmers to participate, imperfect management and maintenance mechanism, and low utilization rate of feces resources. Thirdly, we can coordinate the management of existing standards through the construction of standard system for rural household toilets from four aspects of comprehensive general use, facilities and equipment, construction acceptance and management and protection, which is conducive to clarifying the future standardization work focus, and providing technical support for effective promotion of the "toilet revolution".

Based on the above study, this paper puts forward the following suggestions, in order to promote the construction and implementation of standard system for rural household toilets.

Firstly, Strengthen the top-level design and improve the standard system. The transformation of rural household toilets is a systematic project, involving multiple links such as planning and design, construction, acceptance evaluation, management and maintenance. In the construction process of the standard system, we should use systematic and dynamic thinking way, enhance the goal orientation, strengthen the top-level design of the system, give consideration to both scientificity and practicability, and constantly improve the standard system to meet the actual needs of rural areas in China.

Secondly, Increase technical investment and speed up the development of standards. Based on the understanding of the actual transformation and construction conditions, this paper analyzes the technical difficulties of transformation, increases the investment in technology and product R \& D funds, and focuses on the research and formulation of basic and universal standards with the customer demand oriented and in combination with the standardization objects of rural household toilets, so as to solve the common problems that need to be solved in the process of toilet transformation and provide strong support for the "toilet revolution" in rural areas. Moreover, the national standards, industry standards and local standards should be formulated and revised under the guidance of the system framework, and the standards at all levels should be mutually coordinated, complementary and organically linked.

Thirdly, Strengthen publicity and guidance, promote the implementation of the standard system. In order to promote the implementation of the standard system, it is necessary to establish an efficient operation mechanism of standardization work, innovate the working ideas and methods of standard publicity and implementation, pay attention to the publicity and implementation effect and gradually establish a standard publicity and implementation system from point to face and from face to network. We should pay attention to publicity and implementation at different levels, and carry out publicity and implementation in different forms according to the characteristics of grassroots cadres, rural households, scientific research institutions, enterprises and other relevant implementation subjects, so as to build a talent team for standard publicity and guidance. Based on the local actual situation, administrative departments at all levels and industry associations should adopt various forms of publicity means with rich contents to vigorously publicize the important role of standardization in promoting the "toilet revolution" and enhance the awareness of standardization.

\section{Acknowledgements}

The work presented in this study is supported by the standard technology management special project Research on the Standard System of Rural Household Toilets for Supporting Rural Revitalization of the State Administration for Market Regulation.

\section{References}

1. Li Jie, Wang Yubin, Cheng Pengfei. How can we accelerate the rural "toilet revolution" in China?Based on the experience and enlightenment of typical countries World Agriculture, 2020(10):20-26.

2. Wang Yongsheng, Liu Yansui, Long Hualou. Analysis on the regional characteristics and path of rural toilet transformation in China [J] Journal of Agricultural Resources and Environment, 2019, 36(05):553-560.

3. Shen Zheng, Liu Hongbo, Zhang Yalei. The Current Situation, Issues and Strategies of "Toilet Revolution" in China [J]. Chinese Journal of Environmental Management, 2018, 10(02):45-48.

4. Huo Yafen. Research on the implementation of rural "toilet revolution" policy [D] Henan University, 2019. 